\title{
Interest Rate Derivatives and Asset- Liability Management by Commercial Banks
}

\section{Katerina Simons}

Economist, Federal Reserve Bank of Boston. The author thanks Richard Kopcke, William Lang, and the participants in the seminars at the Federal Reserve Bank of Boston, the meetings of the Atlantic Economic Society, and the SRAC Subcommittee on Financial Structure and Regulation for helpful comments. Timothy Lin provided excellent research assistance.
B ank participation in derivative markets has risen sharply in recent years. The total amount of interest rate, currency, commodity, and equity contracts at U.S. commercial and savings banks soared from $\$ 6.8$ trillion in 1990 to $\$ 11.9$ trillion in 1993, an increase of 75 percent. A major concern facing policymakers and bank regulators today is the possibility that the rising use of derivatives has increased the riskiness of individual banks and of the banking system as a whole.

Banks have long used one type of derivative instrument, namely interest rate futures, to manage interest rate risk (Koppenhaver 1986; Booth, Smith, and Stoltz 1984; Parkinson and Spindt 1986; Franckle and Senchack 1982). However, the development of newer instruments, such as swaps, caps, collars, and floors (see the glossary in Box 1), has greatly expanded the menu of financial technologies available to banks for asset-liability management. In particular, interest rate swaps have become the preferred tool. According to a recent market survey of derivative users, 92 percent of responding financial institutions report using interest rate swaps to manage the interest rate risk of their lending portfolios (Group of Thirty 1993, pp. 40-41).

More recently, studies have focused on the determinants of the broader derivative activities of banks. Sinkey and Carter (1994) studied the determinants of bank use of derivatives between 1989 and 1991. They found that measures of maturity gap and liquidity are consistently significant across banks of different asset sizes. Brewer, Minton and Moser (1994) focused on the relationship between derivative use and bank lending, concluding that the growth of business lending is positively related to the presence of swaps on the bank's books, though the presence of futures had no significant effect on bank lending.

This article contributes to the growing literature on bank derivative use by analyzing the determinants of banks' use of interest rate derivatives between 1988 and 1993. It begins by explaining the use of gap models to measure interest rate risk and the way interest rate derivatives 


\section{Box 1: Glossary}

Interest Rate Cap. An interest rate cap protects a floating-rate borrower against a rise in interest rates. At specified intervals over the life of the contract the seller pays the buyer the difference (if any) between a specified reference rate and the cap rate.

Interest Rate Floor. An interest rate floor protects a floating-rate investor against a decline in interest rates. At specified intervals over the life of the contract the seller pays the buyer the difference (if any) between a floor rate and a specified reference rate.

Interest Rate Collar. An interest rate collar is the purchase of an interest rate cap and the sale of an interest rate floor.

Swap. A swap is an agreement between two parties to exchange a series of cash flows for a period of time. The main categories of swap contracts are interest rate, currency, equity, and commodity swaps.

Plain-Vanilla Interest Rate Swap. The most common type of swap, it consists of an exchange between two parties of fixed-rate interest for floating-rate interest in the same currency.

Swaption. A swaption is a contract that gives the buyer the right, but not the obligation, to enter into a specified swap contract on a future date.

can be used to manage that risk. The article goes on to describe bank use of various interest rate derivatives in more detail and trace growth in recent years. Then it outlines the empirical specification of a model of derivative use and describes the data set used in the analysis. The subsequent section presents the estimation results and interprets parameter estimates. The article concludes by drawing policy implications from the analysis.

\section{Interest Rate Risk and Gap Analysis}

Banks use derivative products mainly to manage interest rate risk. The last 15 years have seen an increased volatility of interest rates compared to the earlier post-World War II era, making the need for accurate measurement and control of interest rate risk particularly acute. At the same time, financial innovations in the field of interest rate derivatives have given banks new and effective instruments for managing that risk.

Interest rate risk arises in bank operations because banks' assets and liabilities generally have their interest rates reset at different times. This leaves net interest income (interest earned on assets less interest paid on liabilities) vulnerable to changes in market interest rates. The magnitude of interest rate risk depends on the degree of mismatch between the times when asset and liability interest rates are reset.

One way to measure the direction and extent of the asset-liability mismatch is through gap analysis, which derives its name from the dollar gap that is the difference between the dollar amounts of rate-sensitive assets and rate-sensitive liabilities. A maturity gap is calculated for a given time period and includes all fixed-rate assets and liabilities that mature in that period and all floating-rate assets and liabilities that have interest rate reset dates in that period.

\section{Banks use derivative products mainly to manage interest rate risk; the increased volatility of interest rates has made the need for accurate measurement and control of interest rate risk particularly acute.}

A bank that has a positive gap will see its interest income rise if market interest rates rise, since more assets than liabilities will exhibit an increase in the interest rate. Similarly, a bank with a negative gap will be hurt by rising rates but will benefit from falling rates.

For example, a bank that issues a 3-month certificate of deposit, and uses the funds to buy a 2-year Treasury note, will see its net interest income eroded if interest rates rise after the first three months because it will have to roll over the CDs at a higher rate, while the rate on the Treasury note will remain the same. In general,

$$
\Delta N I I=(A-L) \times \Delta r,
$$


where NII is net interest income, $A$ is rate-sensitive assets, $L$ is rate-sensitive liabilities and $r$ is the market interest rate. The problem with this simple gap measure is that unless the time interval chosen is very small, assets and liabilities will have their rates reset at different times within that interval. In an extreme case, if the chosen interval is three months, a bank that issues 3-month CDs and funds them by borrowing federal funds overnight will show a three-month gap of zero, even though that bank is exposed to a substantial interest rate risk.

One refinement of a simple maturity gap measure calculates a sequence of periodic maturity gaps, such as a series of three-month gaps for five years. This method has the advantage of more precision, although periodic gaps may be difficult to interpret, especially if they result in a long sequence of alternating negative and positive gaps. On the quarterly Call Reports, banks are required to report the book value of all interest-bearing assets and liabilities, classified according to whether they mature or have interest rate reset dates within the next three months, three months to one year, one to five years, or more than five years. Accordingly, one can calculate the book value of the corresponding periodic gaps for all reporting banks on a quarterly basis.

Figure 1 shows two profiles of average periodic gaps (interest-earning assets less interest-bearing liabilities within the period, divided by total interestearning assets) for all U.S. commercial banks with assets greater than $\$ 100$ million. The first gap profile is for 1988 (the earliest year for which the classifications reported are consistent with the later periods) and the second is for 1993.

The profiles for both years show a negative gap for very short maturities (under three months) and positive gaps thereafter. The gaps have a characteristic humpback shape, reflecting the biggest asset sensitivity in the one- to five-year period. The 1993 profile has a smaller "hump" in that period relative to the 1988 profile, but a larger positive gap for the longest maturities. Both gaps imply that the average bank in both years issued shorter-term liabilities to fund longer-term assets. Thus, in both years the average bank would suffer a loss in interest income when interest rates rose, because the bank would have to pay higher interest on the funds it borrowed, while the interest it received on assets would remain the same.

Ideally, one would want to reduce the measure of interest rate exposure to one number, showing how net interest income would react to a given change in the market interest rate. To provide such an estimate,
Figure 1
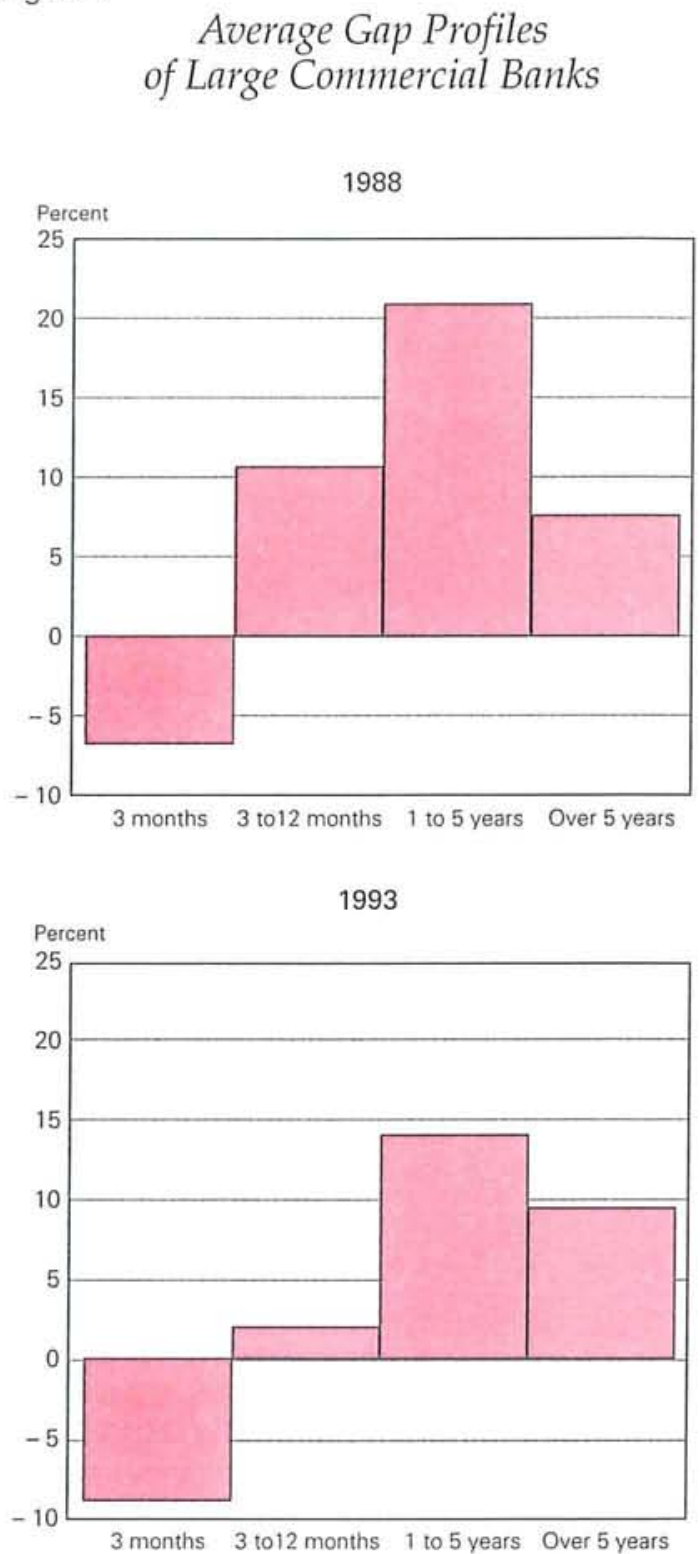

Interest-earning assets less interest-earning liabilities, divided by total interest-earning assets, for all U.S. commercial banks with assets greater than $\$ 100$ million. Source: Call Report data.

the concept of "duration" was developed (Macaulay 1938). Duration represents an account's weighted average time to repricing, where the weights are discounted cash flows. The duration gap is the difference between the duration of assets, weighted by dollars of assets, and the duration of liabilities, weighted by dollars of liabilities. The larger the duration gap, the 


\section{Box 2: A Simple Example of Duration Gap}

Suppose a bank has one asset, a $\$ 300$ loan to be repaid in two equal annual installments, and two liabilities, a \$200 1-year certificate of deposit and a $\$ 100$ 6-month certificate of deposit. For simplicity, suppose also that the interest rates on the loan and both CDs as well as the discount rate used to calculate the net present value are all equal to 5 percent. Since the CDs have one payment each coming at maturity, their durations are equal to their maturities, so that the liability duration weighted by the present value of liabilities is 1 year $\times(\$ 200 / \$ 300)+0.5$ year $\times$ $(\$ 100 / \$ 300)=0.83$ year.

The duration of the loan is not equal to its maturity. To calculate the duration, note that at the interest rate of 5 percent per year, the loan will be repaid in equal installments of $\$ 161.34$ each year. The present values of these cash flows discounted at 5 percent are $\$ 153.66$ and $\$ 146.34$. Thus, the duration of the loan is 1 year $\times$ $(\$ 153.66 / \$ 300)+2$ years $\times(\$ 146.34 / \$ 300)=$ 1.49 years.

The duration gap of this balance sheet is the difference between the duration of assets (1.49 years) weighted by the present value of assets and the duration of liabilities weighted by the present value of liabilities. Thus, the duration gap is ( 1.49 years $\times \$ 300)-(0.83$ years $\times \$ 300)$, or 196 dollar-years.

more sensitive the bank is to the changes in the market interest rate. Box 2 shows a simple example of calculating duration gap.

However, duration gap is an accurate measure of the interest risk only if the term structure of interest rates shifts in parallel, or if any departures from parallel shifts are known in advance. To the extent these conditions are violated, as they often are, interest rate risk cannot be summed up simply in one number.

\section{Managing Interest Rate Risk with Derivative Contracts}

Traditionally, banks controlled interest rate risk by adjusting the maturity or repricing schedules of their assets and liabilities. For example, a bank wish- ing to lengthen the duration of its assets can add long-term government bonds to its securities portfolio. More recently, however, many banks realized that they could accomplish the same goal more cheaply and efficiently by entering into plain-vanilla swaps, where they pay a floating rate, usually denominated in London Interbank Offer Rate (LIBOR), and receive a fixed rate, usually the Treasury rate of equivalent maturity plus a premium. A liability-sensitive bank, on the other hand, can enter into a swap where it pays a fixed rate and receives a floating rate. The bank can also use a "basis" swap, where both sides pay floating rates but the index rates are tied to the bank's cost of funds and lending rate. Specifically, the bank would pay the prime rate and receive LIBOR.

Alternatively, the liability-sensitive bank can buy a cap on LIBOR, so that if LIBOR rises above a certain predetermined level, the seller will pay the bank the difference between LIBOR and that level. A similar approach is a "costless" collar on LIBOR, where the bank buys a LIBOR cap from the dealer and at the same time sells a LIBOR floor to the dealer, with the premium on the bought cap exactly offsetting the premium on the sold floor. In this way, the bank reduces the cost of buying protection from a rise in LIBOR by giving up a potential benefit to its earnings from a fall in LIBOR.

Derivatives can also be used to create synthetic loan and deposit products. For example, a bank can transform a floating-rate loan into a fixed-rate loan by coupling new floating-rate financing with a plainvanilla swap where the bank pays a floating rate in return for receiving a fixed rate.

The advantage of derivatives over more traditional methods of asset-liability management, such as adjusting one's securities portfolio, is that derivatives can transform the duration of the balance sheet while neither increasing it nor incurring significant additional capital requirement. ${ }^{1}$

As a result of these advantages, the use of interest rate derivatives by banks has exploded in recent years. Table 1 illustrates the growth of interest rate contracts at commercial banks with more than $\$ 100$ million in assets. The table shows that futures and forwards

${ }^{1}$ While Treasury securities have zero risk weight in the riskbased capital requirements, their presence on the balance sheet still increases the required "leverage ratio" or the ratio of capital to total assets. In contrast, the capital requirement on off-balance-sheet items, such as swaps, is levied against current and potential replacement cost, which is only a small percentage of the notional principal of the swap. This is appropriate because the notional principal of the swap is not exchanged and is not at risk. 
Table 1

Interest Rate Contracts at Large

Commercial Banks ${ }^{a}$

Notional Values in Billions of Dollars

\begin{tabular}{lcccc}
\hline $\begin{array}{l}\text { Interest Rate } \\
\text { Contracts }\end{array}$ & 1985 & 1990 & 1993 & $\begin{array}{c}\text { \% Growth, } \\
1985 \text { to 1993 }\end{array}$ \\
\hline Swaps & 186.04 & $1,714.97$ & $2,938.18$ & 1,479 \\
Futures and & & & & \\
$\quad$ Forwards & 97.57 & 894.89 & $2,496.43$ & 2,458 \\
Written Options & n.a. & 386.91 & 949.84 & 145 \\
Purchased Options & n.a. & 310.57 & 817.61 & 163 \\
Total & 283.61 & $3,307.34$ & $7,202.06$ & 2,439 \\
\hline
\end{tabular}

n.a. $=$ not available.

U.S. commercial banks with more than $\$ 100$ million in assets.

Source: Call Report data.

grew from $\$ 98$ billion in 1985 to almost $\$ 2.5$ trillion, a growth rate of nearly 2,500 percent. Interest rate swaps grew from $\$ 186$ billion of notional principal in 1985 to almost \$3 trillion in 1993, a growth rate of almost 1,500 percent. Options contracts (including caps, floors, and collars, described above), first reported on Call Reports in 1990, have since more than doubled in notional principal from $\$ 697$ billion to \$1.77 trillion in 1993.

Table 2 compares interest rate derivative use among banks in different size groups in 1985 and 1993. In both years, large banks used derivatives far more frequently than small ones. While fewer than 6 percent of banks with assets between $\$ 100$ million and $\$ 300$ million participated in interest rate derivative markets in 1993, 95 percent of banks with assets between $\$ 5$ billion and $\$ 10$ billion and 100 percent of the largest banks (those with assets over $\$ 10$ billion) did so.

A distinguishing feature of banks' involvement in the derivatives arena is the heavy concentration of activity among a few major players, specifically the top seven banks for derivatives trading, which are among the most active intermediaries in the over-thecounter derivatives market. In 1993, the top seven banks accounted for 85 percent of the notional principal of interest rate contracts of all banks.

These seven banks are dealers as well as users of derivatives. They enter into transactions with custom-

Table 2

Interest Rate Contracts at U.S. Commercial Banks, by Size of Bank

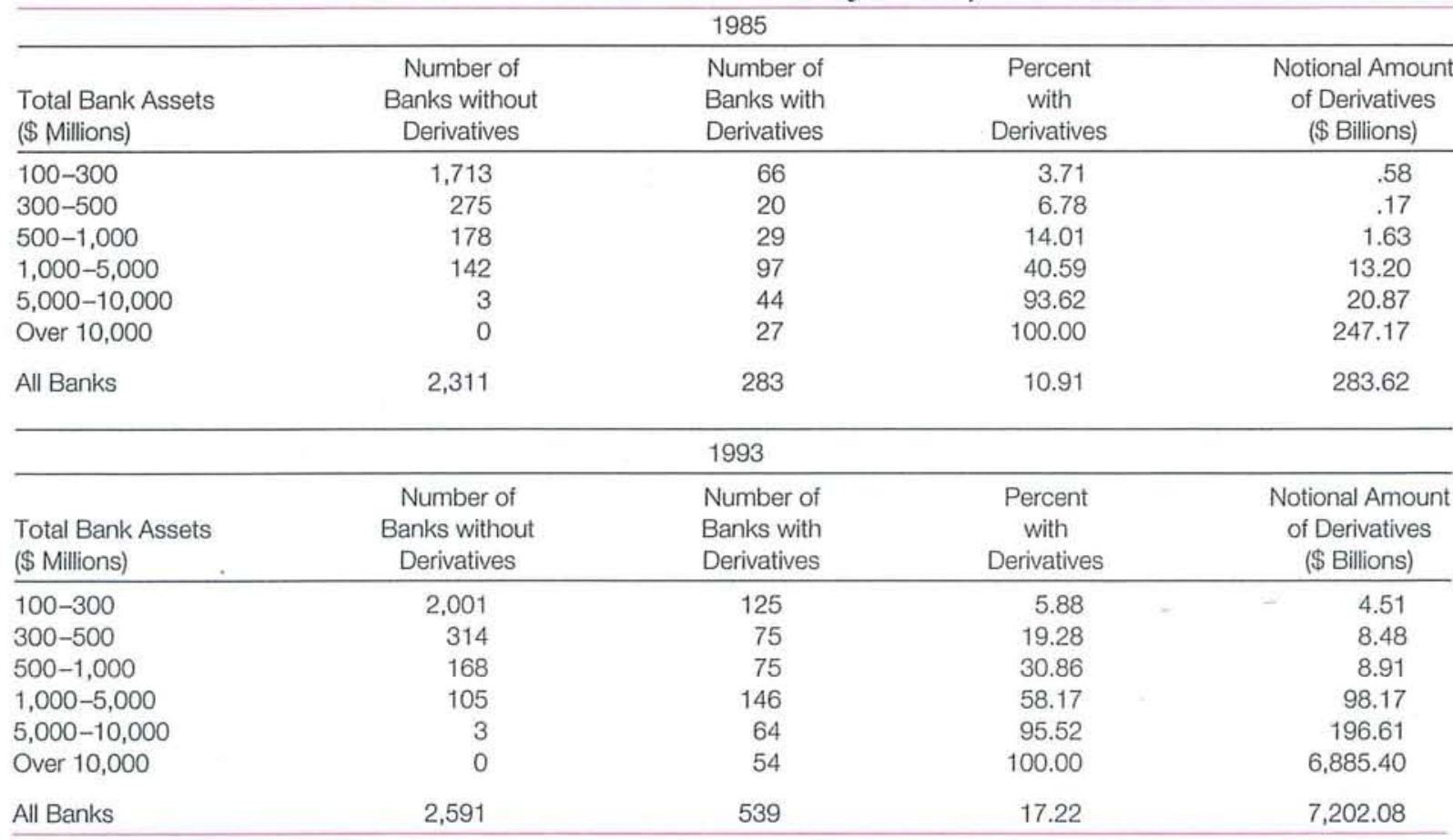

Source: Call Report data. 


\section{Box 3: The Risk of Derivative Instruments}

The risks associated with derivative activities can be divided into five types, namely market, liquidity, credit, operational, and legal risk. These risks are the same as those associated with more traditional financial instruments, such as stocks, bonds, mortgages, or bank deposits. However, because derivatives often combine these risks in new or unfamiliar ways, managing the risk of derivatives may present additional challenges.

\section{Market Risk}

In its most basic form, market risk refers to fluctuations in the price of a financial instrument. The assessment of market risk of derivatives depends on the valuation of underlying instruments. It is relatively straightforward for forward-based derivatives, as a change in the price or rate of the underlying asset generally results in a proportional change in the price of the forward-based derivative.

The assessment of market risk for options-based derivatives tends to be more complex, however. The value of most options is determined by five factors: (i) the price of the underlying asset; (ii) the exercise price of the option; (iii) the time to expiration of the option; (iv) the volatility of the price of the underlying asset; and (v) the discount rate over the life of the option.

Market risk of derivatives must be evaluated on a portfolio basis, in the same way as the market risk of any other financial instrument. An institution may hold a derivative contract to offset the market risk of a specific asset or liability or to reduce the overall market risk of its portfolio. Thus, the market risk of a derivative instrument to the institution is not measured by the price fluctuations of that individual contract. Rather, the relevant issue is whether or not the instrument reduces the overall market risk of the institution's portfolio.

\section{Liquidity Risk}

Liquidity risk refers to the risk of reductions in market liquidity. It arises when a large transaction in a particular instrument can have a noticeable impact on its market price. This makes risk management more difficult and expensive. A somewhat different type of liquidity risk is associated with sudden erosions of liquidity, sometimes associated with an extraordinary event or some other market disruption.

\section{Credit Risk}

Credit risk is the risk that a loss will occur when the counterparty defaults on a derivative contract. This risk fluctuates over time with the value of the contract and, therefore, must be evaluated for both "current" and "potential" exposure. Current exposure is the cost to replace the transaction if the counterparty defaults today. The replacement cost differs from (and is usually much smaller than) the notional principal of a contract, which is simply the hypothetical basis on which payments are calculated. The replacement cost could be positive or negative, depending on the changes in the market value of the contract since the original transaction occurred. When the market value is negative, the remaining party does not incur a loss when its counterparty defaults.

Potential exposure is the potential replacement cost if the counterparty defaults in the future. It is more difficult to assess than current exposure, since it depends on the time path of the future market value of the contract, which cannot be known with certainty. Potential exposure can be understood as a probability that a contract will incur a certain level of credit exposure in the future, and it can be estimated on the basis of the volatility of the price, index, or rate of the instrument underlying the contract.

Credit risk is greater with over-the-counter derivative contracts than with exchange-traded ones. Exchanges significantly reduce credit risk because they require both buyers and sellers to post margin collateral. The contracts are marked to market and settled up on a daily basis. Moreover, the exchanges act as counterparties to all their transactions and all obligations are satisfied through clearing house offset, so that one can cancel an existing position by acquiring an equal but opposing position and be left with zero net exposure. In contrast, over-the-countertraded derivatives are not settled for relatively long periods of time, usually are not collateralized, and are not subject to clearing house offset, which makes them less liquid and increases credit risk.

\section{Operational Risk}

Operational risk is the risk of losses occurring as a result of inadequate systems and internal controls, human error, or management failure. Although this risk exists with all securities, it is increased because of the complexity of many derivatives. The cost of mistakes also can also be higher than with traditional securities owing to greater volatility of some derivative positions.

\section{Legal Risk}

Legal risk is the risk of loss because a contract cannot be enforced. It arises because of uncertain legality or enforceability of contracts in bankruptcy, or because the counterparty lacks the authority to enter into the transaction. 
Table 3

Interest Rate Contracts at the Top Seven U.S. Dealer-Banks, 1993

\begin{tabular}{lccrc}
\hline Bank & $\begin{array}{c}\text { Notional Principal } \\
\text { (\$ Millions) }\end{array}$ & $\begin{array}{c}\text { Replacement Cost } \\
\text { (\$ Millions) }\end{array}$ & $\begin{array}{r}\text { Replacement } \\
\text { Cost/Assets } \\
\text { (Percent) }\end{array}$ & $\begin{array}{r}\text { Replacement } \\
\text { Cost/Equity } \\
\text { (Percent) }\end{array}$ \\
\hline Chemical Bank & $1,049,995$ & 12,390 & 11 & 156 \\
Morgan Guaranty Trust & 755,681 & 19,042 & 19 & 283 \\
Citibank & 564,461 & 8,155 & 5 & 74 \\
Bankers Trust & 534,118 & 10,597 & 16 & 270 \\
Chase Manhattan Bank & 368,616 & 6,541 & 8 & 102 \\
Bank of America & 286,348 & 7,088 & 5 & 61 \\
First Chicago & 166,525 & 3,222 & 9 & 120
\end{tabular}

Source: Call Report data.

ers and with other dealers. Dealers derive revenue from earning a bid-ask spread on a generally balanced portfolio of over-the-counter derivatives. Large dealers also trade for their own accounts, taking positions based on their forecasts of potential moves in interest rates, exchange rates, or commodity prices. They can take these positions by trading in the underlying instruments (such as bonds or currencies) or by using derivative contracts. Thus, proprietary trading may involve derivatives, but derivatives are not necessary for it.

While both market risk and credit risk are present in derivative trading (see Box 3 for a discussion of various types of risk), it is worth noting that it is credit risk, rather than market risk, that has been the cause of almost all bank failures. ${ }^{2}$ Therefore, credit risk as- sumed by banks in their derivative activity is an important concern to bank regulators.

Table 3 lists the top seven dealer-banks in 1993 in terms of the notional principal and the current replacement cost of their interest rate contracts, as well as the ratios of replacement cost to the book value of assets and replacement cost to the book value of equity. The ratio of replacement cost to assets range from a low of 5 percent to a high of 19 percent, while the ratios of replacement cost to equity range from a low of 61 percent to a high of 283 percent. While these replacement costs appear large, they are comparable to credit exposures these banks face in more conven1980.

Table 4

Commercial and Industrial and Commercial Real Estate Lending by the Top Seven U.S. Dealer-Banks, 1993

\begin{tabular}{|c|c|c|c|c|c|c|}
\hline Bank & $\begin{array}{l}\text { Commercial } \\
\text { and } \\
\text { Industrial } \\
\text { Loans } \\
\text { (\$ Millions) }\end{array}$ & $\begin{array}{c}\text { Commercial } \\
\text { and } \\
\text { Industrial } \\
\text { Loans/Assets } \\
\text { (Percent) }\end{array}$ & $\begin{array}{c}\text { Commercial } \\
\text { and } \\
\text { Industrial } \\
\text { Loans/Equity } \\
\text { (Percent) }\end{array}$ & $\begin{array}{c}\text { Commercial Real } \\
\text { Estate Loans } \\
\text { (\$ Millions) }\end{array}$ & $\begin{array}{c}\text { Commercial Real } \\
\text { Estate Loans/ } \\
\text { Assets } \\
\text { (Percent) }\end{array}$ & $\begin{array}{c}\text { Commercial Real } \\
\text { Estate Loans/ } \\
\text { Equity } \\
\text { (Percent) } \\
\end{array}$ \\
\hline Chemical Bank & 19,070 & 16.5 & 240.1 & 3,423 & 3.0 & 43.1 \\
\hline Morgan Guaranty Trust & 8,730 & 8.6 & 129.8 & 59 & .1 & .9 \\
\hline Citibank & 38,798 & 22.1 & 350.6 & 5,435 & 3.1 & 49.1 \\
\hline Bankers Trust & 3,866 & 5.7 & 98.4 & 947 & 1.4 & 24.1 \\
\hline Chase Manhattan Bank & 17,700 & 21.0 & 276.0 & 1,590 & 1.9 & 24.8 \\
\hline Bank of America & 27,628 & 20.2 & 236.2 & 5,137 & 3.8 & 43.9 \\
\hline First Chicago & 5,460 & 15.8 & 203.1 & 942 & 2.7 & 35.0 \\
\hline
\end{tabular}

Source: Call Report data. 
tional lending activities usually considered risky, such as business and commercial real estate loans. Table 4 shows commercial and industrial loans and commercial real estate loans at these seven banks, in dollar amounts and as loan-to-asset and loan-to-equity ratios. As a share of equity capital, the credit exposure on commercial and industrial loans is, in nearly all cases, higher than that of derivatives.

\section{Empirical Specification}

This section analyzes the determinants of derivative use among commercial banks with more than $\$ 100$ million in assets. The classification of interest rate derivatives in the Call Reports is very broad and can include dissimilar instruments. For instance, interest rate swaps include plain-vanilla fixed/floating swaps, basis swaps, index-amortizing swaps, and other, more exotic types of swap contracts. The two categories for interest rate options-" purchased options" and "written options" -include standard put and call options on Treasury securities traded on the exchanges as well as customized over-the-counter instruments such as interest rate caps, collars, floors, or options on swaps. The "futures and forwards" category also includes exchange-traded futures and over-the-counter contracts such as forward rate agreements. Furthermore, long and short futures positions are aggregated (though they were reported separately until 1990).

Because of the very broad nature of the Call Report data, it is impossible to relate the derivative position of a bank to its interest rate risk profile with any degree of precision. Rather, the purpose of this paper is to determine which bank characteristics can explain whether or not a bank uses derivatives and the extent of that use.

The study estimates a fixed-effect model using pooled data from quarterly Call Reports for the period 1988:I through 1993:IV, resulting in a sample of 4,265 banks. Because derivative use is much more widespread among large banks, the primary sample is split into two subsamples: (1) "large" banks (banks with $\$ 5$ billion or more in assets, excluding the seven dealer-banks mentioned above) and (2) "small" banks (banks with more than $\$ 100$ million and less than $\$ 5$ billion in assets). ${ }^{3}$ It will be recalled from Table 2 that almost all banks with $\$ 5$ billion or more in assets use derivatives, so that the problem of estimating a regression where many observations have the value of zero for the dependent variable is thus avoided for that group. A significant portion of the seven dealer-banks' derivative activities is likely to represent dealing and market-making rather than using derivatives for the institution's asset-liability management, and the determinants of the activities are likely to be different. Since it is not possible, using the Call Report data, to distinguish between the two types of the dealers' derivative activities, the seven dealer-banks were excluded, leaving 147 banks in the sample of large banks.

The base equation is as follows:

$$
\frac{D_{j i t}}{A_{i t}}=b_{t}+b x_{i t}+F_{i}+E_{i t} .
$$

The dependent variable is the notional amount of the derivative category $j$ of bank $i$ in quarter $t$ scaled by assets. There are four dependent variables: 1) futures and forwards, 2) interest rate swaps, 3) written and purchased options (available only since 1990:I), and 4) the sum of the notional amounts of the above three categories.

The time-specific intercept, $b$, accounts for timevarying characteristics that influence the use of derivatives and have changed in a uniform way for all banks (for example, new financial technologies, capital requirements, regulatory climate). In contrast, the bank-specific fixed effect, $F$, controls for factors that vary across banks but are not otherwise captured by the independent variables included in the model. These would include management preferences, degree of sophistication and risk aversion, and willingness to use financial innovation.

The vector of independent variables, $X$, consists of the following variables: the logarithm of assets, the ratio of equity to assets, the ratio of nonperforming assets to assets, the ratio of loan-loss reserves (LLR) to nonperforming loans, ${ }^{4}$ the ratio of loan-loss reserves to loans and leases, and four "gap" variables measured as the difference between bank assets and liabilities maturing or repricing in a given time interval ( 0 to three months, three to 12 months, one to five years, and over five years). Following Kim and Koppenhaver (1993), the gap is expressed as the absolute value between assets and liabilities repricing within a given interval, divided by total assets.

\footnotetext{
${ }^{3} \mathrm{~A}$ few institutions were counted in both subsamples as their assets grew to exceed $\$ 5$ billion during the sample period.

${ }^{4}$ Nonperforming loans are defined as loans and leases 90 or more days past due or in nonaccrual status. Nonperforming assets are defined as loans and leases 90 or more days past due or in nonaccrual status plus foreclosed property (other real estate owned, excluding direct and indirect investments in real estate ventures).
} 
The presence of the equity-to-asset ratio and the standard measures of asset quality such as the ratios of nonperforming assets to assets, loan-loss reserves to nonperforming loans, and loan-loss reserves to total loans and leases, are meant to capture the regulatory environment. An important reason why managing interest rate risk through derivatives may be preferable to on-balance-sheet management is that off-balance-sheet contracts entail lower capital requirements. Thus, banks with lower capital ratios may be expected to be bigger users of derivatives, other things being equal. Similarly, banks with relatively poor asset quality (as measured by high levels of nonperforming assets relative to total assets or low levels of loan loss reserves relative to nonperforming loans) will need to conserve capital and might find derivatives to be a more desirable, capital-efficient way to manage the balance sheet. On the other hand, the use of derivatives may be perceived by regulators as risky, and poorly capitalized banks and banks with weak asset quality or low loan-loss reserves would be subject to more scrutiny or restrictions by regulators when they attempt to use derivatives, thus discouraging the use of derivatives by such banks.

The four "gap" measures are meant to represent a crude measure of the interest rate risk assumed by the bank before its derivative position is taken into account. Larger absolute values of the gap measures indicate a greater sensitivity to interest rate changes on the part of the bank. A bank can reduce its interest rate exposure by hedging with derivative positions.

\section{Results}

Table 5 reports regression results for banks with assets below $\$ 5$ billion, while Table 6 reports the results for the banks with assets of $\$ 5$ billion or more. The gap measures show no consistent relationship to the use of derivatives. For instance, while a positive and significant relationship exists for large banks between the one- to five-year gap and the use of all derivatives, the relationship between these variables is negative and significant for the small bank subsample.

A somewhat unexpected result of the regressions is the negative relationship between the intensity of derivative use and bank size. Given that large banks use derivatives more frequently than small banks (Table 2), one might have expected the intensity of their use also to be higher.

It has sometimes been suggested that barriers to entry into derivative markets due to economies of scale prevent smaller institutions from participating. However, this argument has more validity for the over-the-counter instruments than for the exchangetraded ones. Over-the-counter derivatives are customized, must be purchased from a dealer, and may have large, indivisible contract denominations. The argument is less compelling for exchange-traded instruments, which are available even to retail investors.

The regression results in Tables 5 and 6 show a negative relationship between the use of derivatives and size for all derivative categories, for both large and small bank subsamples. The only exception is the regression for swaps for banks with under $\$ 5$ billion in

\section{A somerwhat unexpected result of the regressions is the negative relationship between the intensity of derivative use and bank size, with the exception of swaps for banks with under $\$ 5$ billion in assets.}

assets, which has a positive and significant coefficient for bank size (Table 5, Column 2). It will be recalled that swaps are over-the-counter instruments, where barriers to entry may indeed be present for smaller banks, while the other regression categories (options, and futures and forwards) include both the exchangetraded and the over-the-counter instruments.

The relationship between the equity-to-asset ratio and the use of derivatives is ambiguous. For both the small and the large bank subsamples, the relationship is negative and statistically significant for futures, but positive and significant for swaps. It is possible that swaps are perceived as more risky and invite greater scrutiny from the regulators in weaker-capitalized banks. This may allow better-capitalized banks to participate in the swap market to a greater extent.

Among large banks, those with weaker asset quality (as measured by a higher ratio of nonperforming assets to assets and a smaller ratio of loan-loss reserve to loans) appear to be bigger users of derivatives than banks with relatively stronger asset quality. In the large bank subsample, the coefficient for nonperforming assets is positive and significant, while the coefficient for loan-loss reserves is negative and significant for futures, swaps, and all derivatives. 
Table 5

The Determinants of Derivative Use: Commercial Banks with Assets of Less Than $\$ 5$ Billion $^{a}$

Estimation Method: Fixed Effects, 1988:I to 1993:IV

\begin{tabular}{|c|c|c|c|c|}
\hline Independent Variable & Futures/Assets & Swaps/Assets & Options/Assets & $\begin{array}{c}\text { All Derivatives/ } \\
\text { Assets }\end{array}$ \\
\hline Log Assets & $\begin{array}{l}-.002^{*} \\
(2.17)\end{array}$ & $\begin{array}{l}.011^{*} \\
(10.2)\end{array}$ & $\begin{array}{l}-.020^{* *} \\
(5.00)\end{array}$ & $\begin{array}{l}-.003 \\
(1.04)\end{array}$ \\
\hline Equity/Assets & $\begin{array}{l}-2.74 \mathrm{E}-4^{* *} \\
(2.52)\end{array}$ & $\begin{array}{l}6.50 \mathrm{E}-4^{. *} \\
(5.27)\end{array}$ & $\begin{array}{c}-6.31 \mathrm{E}-4 \\
(1.28)\end{array}$ & $\begin{array}{l}6.26 \mathrm{E}-4^{*} \\
(1.67)\end{array}$ \\
\hline Nonperforming Assets/Assets & $\begin{array}{l}2.99 \mathrm{E}-5 \\
(.293)\end{array}$ & $\begin{array}{l}9.38 \mathrm{E}-6 \\
(.081)\end{array}$ & $\begin{array}{l}-.001^{* *} \\
(2.51)\end{array}$ & $\begin{array}{c}-1.93 \mathrm{E}-4 \\
(.551)\end{array}$ \\
\hline LLR/Nonperforming Loans & $\begin{array}{c}-9.88 \mathrm{E}-10 \\
(.025)\end{array}$ & $\begin{array}{c}-1.15 \mathrm{E}-8 \\
(.259)\end{array}$ & $\begin{array}{c}-3.14 \mathrm{E}-8 \\
(.243)\end{array}$ & $\begin{array}{c}-3.80 \mathrm{E}-8 \\
(.281)\end{array}$ \\
\hline LLR/Loans and Leases & $\begin{array}{l}2.42 \mathrm{E}-5 \\
(.163)\end{array}$ & $\begin{array}{l}2.16 E-4 \\
(1.28)\end{array}$ & $\begin{array}{c}.001^{*} \\
(1.70)\end{array}$ & $\begin{array}{c}.001^{\circ} \\
(2.14)\end{array}$ \\
\hline Gap -3 months & $\begin{array}{l}3.34 \mathrm{E}-5 \\
(1.41)\end{array}$ & $\begin{array}{l}-1.03 E-4^{*} \\
(3.85)\end{array}$ & $\begin{array}{l}-3.75 E-4^{* *} \\
(3.83)\end{array}$ & $\begin{array}{l}-3.70 E-4^{* *} \\
(4.54)\end{array}$ \\
\hline Gap -3 to 12 months & $\begin{array}{l}1.59 \mathrm{E}-5 \\
(.605)\end{array}$ & $\begin{array}{l}5.90 \mathrm{E}-5^{*} \\
(1.99)\end{array}$ & $\begin{array}{l}7.26 \mathrm{E}-5 \\
(.607)\end{array}$ & $\begin{array}{l}1.53 \mathrm{E}-4^{*} \\
(1.70)\end{array}$ \\
\hline Gap-1 to 5 years & $\begin{array}{c}-4.78 E-5^{*} \\
(1.96)\end{array}$ & $\begin{array}{l}2.12 E-5 \\
(.768)\end{array}$ & $\begin{array}{l}-3.42 \mathrm{E}-4^{* *} \\
(3.36)\end{array}$ & $\begin{array}{l}-2.53 \mathrm{E}-4^{* *} \\
(3.01)\end{array}$ \\
\hline Gap over 5 years & $\begin{array}{c}-3.64 \mathrm{E}-6 \\
(.120)\end{array}$ & $\begin{array}{l}-3.50 \mathrm{E}-4^{* *} \\
(10.2)\end{array}$ & $\begin{array}{c}-9.12 \mathrm{E}-5 \\
(.757)\end{array}$ & $\begin{array}{l}-4.05 \mathrm{E}-4^{* *} \\
(3.90)\end{array}$ \\
\hline $\mathrm{R} 2$ & 8.27E-4 & .026 & .003 & .008 \\
\hline SSR & 72.3 & 92.4 & 448.9 & 853.8 \\
\hline SER & .034 & .038 & .102 & .116 \\
\hline Number of banks & 4,185 & 4,185 & 3,834 & 4,185 \\
\hline Number of observations & 68,118 & 68,118 & 46,699 & 68,118 \\
\hline
\end{tabular}

aAnd more than $\$ 100$ million.

Absolute values of $\mathrm{t}$-statistics in parentheses.

-Significant at the 5\% confidence level.

*-Significant at the $1 \%$ confidence level.

To summarize, while these results do not explain much of the variation in bank derivative use, particularly for small banks, certain patterns emerge. First, the study found a positive relationship between bank size and the use of swaps for the small-bank subsample. Second, well-capitalized banks appear to use swaps more intensively, but not futures. This is not surprising given that creditworthiness of swap counterparties is an important consideration for market participants, while it is not a concern for futures, where the exchange stands behind the transactions. Third, large banks with weaker asset quality are bigger users of swaps and futures than banks with stronger asset quality, possibly because they are more capital-constrained or have more taste for risk. Fourth, derivative use had no consistent relationship to the bank's gap profile. While hedging is consistent with a positive relationship, even if such a relationship were found, it could not be considered to be explicit evidence of hedging. The available data are not, in fact, sufficient to determine if a bank uses derivatives to reduce the interest rate risk inherent in its balance sheet position, or to increase it.

\section{Conclusion}

This study has used the quarterly Call Report data to shed some light on the pattern of derivative use by U.S. commercial banks. The study has found 
Table 6

The Determinants of Derivative Use: Commercial Banks with Assets of $\$ 5$ Billion or More ${ }^{a}$ Estimation Method: Fixed Effects, 1988:I to 1993:IV

\begin{tabular}{|c|c|c|c|c|}
\hline Independent Variable & Futures/Assets & Swaps/Assets & Options/Assets & $\begin{array}{c}\text { All Derivatives/ } \\
\text { Assets }\end{array}$ \\
\hline Log Assets & $\begin{array}{l}-.162^{* *} \\
(6.61)\end{array}$ & $\begin{array}{l}-.135^{* *} \\
(5.28)\end{array}$ & $\begin{array}{l}-.093^{*} \\
(2.18)\end{array}$ & $\begin{array}{l}-.510^{* *} \\
(7.93)\end{array}$ \\
\hline Equity/Assets & $\begin{array}{l}-.012^{* t} \\
(3.17)\end{array}$ & $\begin{array}{l}.010^{* *} \\
(2.46)\end{array}$ & $\begin{array}{l}-.001 \\
(.151)\end{array}$ & $\begin{array}{c}.009 \\
(.839)\end{array}$ \\
\hline Nonperforming Assets/Assets & $\begin{array}{l}.010^{* *} \\
(3.63)\end{array}$ & $\begin{array}{l}.007^{*} \\
(2.25)\end{array}$ & $\begin{array}{c}-.003 \\
(.537)\end{array}$ & $\begin{array}{l}.029^{* *} \\
(3.95)\end{array}$ \\
\hline LLR/Nonperforming Loans & $\begin{array}{l}5.01 \mathrm{E}-5 \\
(1.13)\end{array}$ & $\begin{array}{c}-1.32 \mathrm{E}-5 \\
(.284)\end{array}$ & $\begin{array}{l}1.39 E-5 \\
(.220)\end{array}$ & $\begin{array}{l}7.63 E-5 \\
(.653)\end{array}$ \\
\hline LLR/Loans and Leases & $\begin{array}{l}-.041^{*} \\
(9.27)\end{array}$ & $\begin{array}{l}-.022^{* *} \\
(4.78)\end{array}$ & $\begin{array}{l}.010 \\
(.999)\end{array}$ & $\begin{array}{l}-.090^{*} \\
(7.72)\end{array}$ \\
\hline Gap-3 months & $\begin{array}{l}2.26 E-4 \\
(.338)\end{array}$ & $\begin{array}{r}.001 \\
(1.53)\end{array}$ & $\begin{array}{l}-.003^{* *} \\
(2.88)\end{array}$ & $\begin{array}{l}.001 \\
(.816)\end{array}$ \\
\hline Gap -3 to 12 months & $\begin{array}{c}-5.38 E-4 \\
(.547)\end{array}$ & $\begin{array}{c}-1.58 \mathrm{E}-4 \\
(.153)\end{array}$ & $\begin{array}{l}2.72 E-5 \\
(.017)\end{array}$ & $\begin{array}{c}-2.15 \mathrm{E}-4 \\
(.083)\end{array}$ \\
\hline Gap -1 to 5 years & $\begin{array}{l}3.63 E-4 \\
(.502)\end{array}$ & $\begin{array}{c}.003^{* *} \\
(4.29)\end{array}$ & $\begin{array}{l}6.75 E-4 \\
(.568)\end{array}$ & $\begin{array}{l}.005^{* *} \\
(2.56)\end{array}$ \\
\hline Gap over 5 years & $\begin{array}{l}4.85 E-4 \\
(.712)\end{array}$ & $\begin{array}{c}-2.44 E-4 \\
(.342)\end{array}$ & $\begin{array}{l}-.003^{* *} \\
(3.06)\end{array}$ & $\begin{array}{l}-.004^{*} \\
(1.96)\end{array}$ \\
\hline $\mathrm{R} 2$ & .103 & .190 & .064 & .196 \\
\hline SSR & 45.4 & 49.9 & 47.7 & 314.0 \\
\hline SER & .145 & .152 & .181 & .382 \\
\hline Number of banks & 147 & 147 & 142 & 147 \\
\hline Number of observations & 2,329 & 2,329 & 1,627 & 2,329 \\
\hline
\end{tabular}

aExcluding top seven U.S. dealer-banks.

Absolute values of $t$-statistics in parentheses.

-Significant at the $5 \%$ confidence level.

*Significant at the $1 \%$ confidence level.

that for banks with less than $\$ 5$ billion in assets, larger banks tend to use interest rate swaps more intensively, while there was no clear relationship between size and other interest rate derivatives. In addition, the study has found that for banks with more than $\$ 5$ billion in assets, those with weaker asset quality tend to be more intensive users of derivatives than banks with better asset quality. These results, while intriguing, do not give a clear indication of how derivatives are used to manage interest rate risk, particularly whether they are used to increase or reduce that risk. Given that banks and the federal regulatory agencies spend time and effort to collect and process financial data through the Call Report system, it is disappointing that Call Report data are not more revealing. Call Reports are changed periodically to make the information in them more relevant, and a few modifications to the way derivative activities currently are reported would allow a clearer assessment of bank derivative activities and their risk.

First, Call Reports should distinguish the short and the long positions in futures and forwards, call and put options written and bought, and fixed versus floating sides in interest rate swaps. In addition, swaps and forward contracts should be broken down into the same maturity brackets currently used for loans and securities. This would allow one to adjust gap analysis for derivatives and gain a clearer picture of the relationship between interest rate risk and derivative use.

Rather than providing a definitive measure of risk, the purpose of the Call Report is to give analysts 
and supervisors a screening mechanism that might point to the need to gather more detailed information. Expanding the reporting of off-balance-sheet derivatives mentioned above would go further in making the risk of derivative activities more transparent and highlighting potential problems requiring the supervisors' attention. It is important to emphasize, however, that the Call Report is not a substitute for a bank examination, and gap analysis is not a meaningful measure of interest rate risk in any but the simplest of cases. Large banks active in derivative trading have developed more sophisticated models to gauge the risk exposure arising from their trading activities. Even smaller banks' balance sheets are usually too complex to be amenable to a simple gap analysis. This is because even banks that do not use the derivative contracts discussed here, namely swaps, futures, and options, have assets on their balance sheets that have imbedded derivative characteristics. In particular, certain mortgage securities and "structured notes," that

\section{References}

Booth, James R., Richard L. Smith, and Richard W. Stoltz. 1984. "Use of Interest Rate Futures by Financial Institutions." Journal of Bank Research, vol. 15 (Spring), pp. 15-20.

Brewer, Elijah, Bernardette Minton, and James Moser. 1994. "The Effect of Bank-Held Derivatives on Credit Accessibility." In The (Declining?) Role of Banking. Federal Reserve Bank of Chicago. Proceedings of the 30th Annual Conference on Bank Structure and Competition, (May), pp. 208-28.

Franckle, C. and A. Senchack. 1982. "Economic Considerations in the Use of Interest Rate Futures." Journal of Futures Markets, vol. 2 (Spring), pp. 107-16.

Group of Thirty. 1993. Derivatives: Practices and Principles. Washington, D.C.: Group of Thirty.

Kim, Sung-Hwa and G. D. Koppenhaver. 1993. "An Empirical Analysis of Bank Interest-Rate Swaps." Journal of Financial Services Research (February), pp. 57-72. is, debt securities whose cash flow characteristics depend on one or more indices and/or that have embedded forwards or options, have risks not reflected in their maturities and have proved especially volatile in the current interest rate environment.

While improving Call Reports would be useful for bank analysts, the federal and state regulatory agencies, and others concerned with the health of the nation's banking system, it is only a small step in the direction of meaningful derivative disclosure. Even if disclosure were improved, however, some uncertainty would always remain for outsiders about the risks of the positions taken by market participants. Nevertheless, as financial innovation continues to spread, a wider spectrum of banks will begin using derivatives for asset-liability management. This makes it especially important to develop comprehensive and uniform reporting methods that will permit meaningful disclosure of interest rate risk for all financial institutions.
Koppenhaver, Gary D. 1986. "Futures Options and Their Use by Financial Intermediaries." Federal Reserve Bank of Chicago, Economic Perspectives (January), pp. 18-31.

Macaulay, Frederick R. 1938. Some Theoretical Problems Suggested by the Movements of Interest Rates, Bond Yields and Stock Prices in the U.S. since 1856. New York: National Bureau of Economic Research.

Parkinson, Patrick and Paul Spindt. 1986. "The Use of Interest Rate Futures by Commercial Banks." In Myron Kwast, ed., Financial Futures and Options in the U.S. Economy, pp. 221-48. Washington, D.C.: Board of Governors of the Federal Reserve System.

Sinkey, Joseph and David Carter. 1994. "The Derivative Activities of U.S. Commercial Banks." In The (Declining?) Role of Banking. Federal Reserve Bank of Chicago. Proceedings of the 30th Annual Conference on Bank Structure and Competition, (May), pp. 16585 . 